\title{
Use of ICT in decision making of agricultural marketing: Factors determining
} of farmers' involvement

\author{
Nasida Binta Wahab Tonny, ${ }^{\otimes}$ Md Salauddin Palash and Md Moniruzzaman
}

Department of Agribusiness and Marketing, Faculty of Agricultural Economics and Rural Sociology, Bangladesh Agricultural University, Mymensingh, Bangladesh

\begin{tabular}{|c|c|}
\hline ARTICLE INFO open $\odot$ access & Abstract \\
\hline Article history: & \multirow{8}{*}{$\begin{array}{l}\text { The paper investigated the magnitude of social parameters' impacts on effective use of Information and } \\
\text { Communication Technology (ICT) in agricultural marketing by the farmers. In addition, how farmers } \\
\text { identify information sources and how they access to those sources in selected areas of Jamalpur district } \\
\text { were also examined. Purposive sampling method was used in this investigation and data were collected } \\
\text { from eighty farmer's thorough survey questionnaire. Descriptive statistics, Likert scale and multivariate } \\
\text { regression model were used to analyze the data. Multivariate regression model was specified and } \\
\text { estimated to identify the factors affecting use of ICT by farmers. The outcome of this study highlights } \\
\text { important factors for the use of ICT. It is evident from the findings that the users of ICT are getting better } \\
\text { quality information and are hence making significantly better decisions on all aspects of agricultural } \\
\text { marketing. Regression analysis revealed that two factors i.e. cultivated land of farmers and level of } \\
\text { education were the important factors of using of ICT by farmers. Modern ICT tool such as mobile phone } \\
\text { was the most used device by the farmers due to low price and availability. They collected most of the } \\
\text { information regarding marketing activities of their produce by mobile phone from other progressive } \\
\text { farmers, traders and agricultural extension workers. Social imperative findings of this paper might be } \\
\text { helpful for the policy maker to emphasis on further extension of mobile phone based agricultural } \\
\text { marketing information system in Bangladesh. }\end{array}$} \\
\hline Received : 21 October 2018 & \\
\hline Accepted : 04 April 2019 & \\
\hline Published: 30 June 2019 & \\
\hline $\begin{array}{l}\text { Keywords: } \\
\text { ICT, Agricultural Marketing, } \\
\text { Mobile Phone, OLS, Bangladesh }\end{array}$ & \\
\hline Correspondence: & \\
\hline & \\
\hline 凶: palash@bau.edu.bd & \\
\hline
\end{tabular}

Copyright:

(c) (i)

(C2019 by authors and BAURES. This work is licensed under the Creative Commons Attribution International License (CC By 4.0).

\section{Introduction}

Agriculture is one of the most vital sectors for economic and social development in Bangladesh. Application of information and communication technologies (ICT) by farmers can benefit tremendously from producing to marketing of agricultural products. Agricultural products marketing need access to updated and exact information for improving the quality of the decision making. Agricultural information played a very important role to enhance the agricultural development which in turn effect on economic development of Bangladesh (Hasan et al. 2009). The use of information and communication technologies (ICTs) is an approach of linking smallholder farmers to the market and provide them with current marketing information. Based on the information, farmers can make decision on production and marketing effectively. The aim of using the ICT in agricultural marketing is to increase farmers' income and improve productivity (Mawazo, 2015). In Bangladesh, cultivation is dependent on the uncertainties and average output is below the optimum level. Addition of value in agriculture requires technological, institutional and price incentive changes to raise the productivity of the small farms (Todaro, 2000). The agricultural marketing process can be hampered by imperfect market information and high transaction costs
(Dao, 2004). Use of ICT can improve the situation of imperfect information in agricultural marketing. As a result, product demand-supply flow can maintain by creating communication channel with the producer and buyer. In addition, disorganized market can also be organized through ICT in agriculture. ICT in agricultural marketing is a tool for information generation and dissemination (Rahman, 2016).

There are several factors which are adversely affecting the use of ICT devices and applications. The factors which are significantly influencing are age, education and knowledge level of ICT, the amount of land under cultivation, distance to ICT center, number of pieces of agricultural land, experience in cultivation (Vosough, 2015). Vakilzavareh et al. (2014) also mentioned some issues such as inadequate knowledge of farmers in the use of ICT, farmer's lack of awareness of the benefits of ICTs and the lack of comprehensive information system are high prioritized factors affecting the use of ICT by farmers. The system which is providing information must be in user-friendly form, easy to access, costeffective and well protected from unauthorized accesses (Kashem et al. 2010). Farmers have to make personal travel to market frequently and this is the most common method of obtaining market information traditionally. 
But with the help of ICT rather than having to walk miles to meet a trader in local market, farmers can make a voice call to know whether price and quantities demanded for a product of that day are worth enough for the travel effort. It will save time and reduce the cost of marketing of farmers.

It helps to reduce asymmetries of information between traders and producers, lowering transaction costs, and enhancing farmers' ability to fine-tune their production strategies to match the accelerating rates of change in consumer demand and marketing channels (Rao, 2007). It will also help the farmers to improve their farm income and build trust with trading partners. Farmers can get the facilities of more efficient use of existing transport, storage, packaging and processing technique through the use of ICT (Aker, 2011). For sustainable development of agriculture and national economy, emphasis on ICT and its use in agriculture is very important.

\section{Methodology}

The study was conducted in Jamalpur District; from where 8 unions of 3 upazilas were selected such as Dewanganj, Bahadurabad, Chikajani, Hativanga and Dangdhara union of Dewanganj upazila; Bakshiganj and Merur Char union of Bakshiganj upazila; and Islampur union of Islampur upazila. Purposive sampling technique was adopted to collect the data from the farmers. Eighty farmers from eight unions were selected for conducting the study. Of them, 45 farmers were found who were currently using different ICT sources to collect information for marketing their agricultural produce and 35 farmers were found as non-user of ICT sources. ICT users used only one ICT based sources for collecting information from more than one ICT based sources such as mobile phone, internet, televisions and radios. In this case, most of them have basic knowledge on the uses of these devices. They use these devices by their own means or with the help of any family members who has better knowledge about it. The non-user of ICT was ICT used only one ICT based sources for collecting information from traditional sources such as traders, progressive farmers and sometimes extension workers. Data were collected from both primary and secondary sources. Primary data were collected through direct personal interview from the respondents. Secondary data and other relevant information were collected from market reports, journals, publications, Bangladesh Institute of ICT for Development (BIID) and others relevant sources. Descriptive analysis was used to analyze characteristics of the respondents. In addition, Likert scale (Likert, 1932) was used to examine the farmer's perceptions about quality of their decision regarding different marketing practices. Predetermined opinions were presented to the respondents and the Likert scaling technique was used to rate the opinions. There were mainly nine dimensions on which farmers collect information for marketing their produce. So, the researcher recorded the quality perceptions of farmers on those aspects. Each opinion was given a scale of one to five such as: very good takes a scale of 1 , good a scale of 2 , average a scale of 3 , poor a scale of 4 , very poor a scale of 5 .

Analysis of Variance is a method of estimation how much of total variation in a set of data can be attributed to certain assignable causes of variation and how much can be attributed to chance factor and then comparing these estimates due to chance factor to test the equality of means. Analysis of variance is the separation of variance ascribable to one group of causes from the variance ascribable to other group. According to Venkatesh, Brown, \& Bala (2013), researchers can examine relationships between two variables by comparing the mean of the dependent variable between two or more groups within the independent variable.

Here, the researcher has collected information on nine dimensions of agricultural marketing which are related to agricultural marketing. These nine practices are generally performed by farmers to collect marketing related information which helps them to take better decision for marketing their products. The researcher recorded quality perceptions of both groups i.e. ICT user and non-user farmers. At first the quality perceptions of farmers on various aspects of marketing were recorded on a five point Likert scale. Then the mean value of responses on various marketing practices and Analysis of Variance between two groups were performed to see whether there was any difference in decision quality between ICT user and non-user farmers. So the following hypothesis was set for this analysis.

HO: There is no difference in quality of decision making for marketing agricultural produce between ICT user and non-user farmers

Multivariate regression model was used to identify factors affecting the use of ICT by farmers. In this case, the dependent variable was the total score of the respondents on different marketing practices and the independent variables were age, education level, size of family, farming experience, basic ICT skill, and cultivated land of the farmers.

$$
\begin{aligned}
& \mathrm{Y=} \beta_{0}+\beta_{1} X_{1}+\beta_{2} X_{2}+\beta_{3} X_{3}+\beta_{4} X_{4}+\beta_{5} X_{5}+\beta_{6} X_{6} \\
& +\beta_{7} X_{7}+e_{i} \\
& \text { Where, } \\
& Y=\text { Total score of the respondents on different } \\
& \text { marketing practices; } \\
& X_{1}=\text { Age of the respondent; } \\
& X_{2}=\text { Cultivated land of the respondent; } \\
& X_{3}=\text { Farming experience of the respondent; } \\
& X_{4}=\text { Household size of the respondent; } \\
& X_{5}=\text { Education of the respondent; } \\
& X_{6}=\text { Basic ICT skill; } \\
& X_{7}=\text { Skill upgrading training; } \\
& \beta_{0} \text { to } \beta_{7}=\text { Regression coefficients; and } \\
& e_{i}=\text { Error term. }
\end{aligned}
$$


Before estimating the parameters, multicollinearity tests were performed using appropriate test statistics. A VIF (Variance Inflation Factor) for continuous variables and contingency coefficient values for discrete variables were computed to check the existence of multicollinearity problem (James, et al. 2017). The independent variables which are expected to influence the dependent variable are presented in the following Table 1.

\section{Table 1. Description of the dependent and independent variable}

\begin{tabular}{|c|c|c|}
\hline Variables & Type & Unit \\
\hline \multicolumn{3}{|l|}{ Dependent } \\
\hline $\begin{array}{l}\text { Likert scale index in quality perceptions of } \\
\text { farmers on various aspects of marketing activities }\end{array}$ & Continuous & Unit \\
\hline \multicolumn{3}{|l|}{ Independent } \\
\hline Age of the farmers & Continuous & Year \\
\hline Cultivated land of the farmers & Continuous & Acre \\
\hline Experience in farming & Continuous & Year \\
\hline Family size & Discrete & Number of family member \\
\hline Education level of the farmers & Categorical & $\begin{array}{l}0=\text { Not educated, } 1=\text { below grade } 8^{\text {th }}, 2= \\
\text { grade } 8^{\text {th }} \text { to } 12^{\text {th }}, 3=\text { above } 12^{\text {th }} \text { grade, } 4= \\
\text { Adult Education }\end{array}$ \\
\hline Basic ICT skill & Dummy & $0=$ no, $1=$ yes \\
\hline Skill upgrading training & Dummy & $0=$ no, $1=$ yes \\
\hline
\end{tabular}

\section{Results and Discussion Social parameters}

An attempt is made to describe some socioeconomic characteristics of sampled farmers. Information about age, education, farm category and cultivated land, and household size were considered to document the socioeconomic characteristics. These aspects are important to understand the farmers' level of living, socioeconomic environment in which they live, and the nature and the content of their participation in economic activities.

The selected farmers were grouped into three categories according to their age. Looking at the age distribution of respondents, more than half (64\%) of them were found between the age of 41-60. It indicates that most of the sampled farmers belonged to active age range in human life cycle. The rest $26 \%$ and $10 \%$ of the respondents were between the age of 21-40 and above 60 years respectively. With regard to their educational status, less than a quarter $(24 \%)$ of respondents had never been in school, while $35 \%$ claimed to study until grade 8 or even less. Moreover, $15 \%$ of the respondents reported to reach grade 9 to grade 12 . And the rest $10 \%$ and $16 \%$ of the respondents completed above 12 grade and adult education, respectively. Educated farmers were always in a favorable position in using information from different ICT sources.

The selected farmers were grouped into four categories according to their amount of land. According to the Bangladesh Bureau of Statistics, farmers who had land between 0.05-0.49 acres and 0.50-2.49 acres were categorized as marginal and small farmers, respectively. Land between 2.50-7.49 acres were categorized as middle farmers and who had land above 7.50 acres were categorized as large farmers. The farm category of respondents showed that more than half $(51 \%)$ of the respondents were medium farmers whereas $11 \%$ were marginal farmers, $15 \%$ were small farmers and $23 \%$ of them were large farmers.

\section{Sources of information and its access by the farmers}

With the improvement and easy availability of new modern technology, the use of ICT in agricultural purpose is increasing day by day. For collecting information about agricultural input, farmers were mostly dependent on mobile phone and other ICT sources. Majority of the farmers $(81 \%)$ used mobile phone to get input related information followed by computer $(16 \%)$, radio $(6 \%)$ and Television $(5 \%)$. A large portion of the farmers (90\% and 59\%) physically contacted with input traders and extension workers respectively for agricultural input related information.

In the case of agricultural marketing information, the major source of information was also mobile phone. More than four-fifth (i.e., 91\%) of the respondents used mobile phone to collect marketing information to sell their products. The second source of information was computer with internet connection. About $41 \%$ of the total respondents collected market information browsing different websites. This service was provided by the the Zill Bangla Sugar Mills in Dewanganj area. They provided different marketing related information through using computer to the farmer in regular basis. The farmers were provided different marketing information such as price of the products in the terminal market, availability of buyers for the product, proper market planning, inputs price, etc. The up-to-date price of different agricultural products and inputs which were available in DAM website, online agricultural news portal and other reliable sources were discussed in the weekly meeting by using projector and laptop with internet connection. About $45 \%$ of the total respondents 
collected information through Television and only $24 \%$ of the total respondents collect information through radio.

With regard to the use of application to access ICT for getting market information, $91 \%$ of the respondents collected information through voice calling. About $75 \%$ of the total respondents used short message service to get price related information and $51 \%$ of the respondents collected information by using internet. Moreover, some progressive farmers owned computer with internet connection who collected information with the help of their educated family members. About $39 \%$ of the total respondents collected information through watching different programs on television such as special news or bulletin on marketing information of agricultural produces that was telecasted by different channel at regular intervals. In addition, about $15 \%$ of the respondents collected information through radio.

There were several reasons which were identified in the study area for using information through ICT sources. In the study area, 45 farmers who were ICT users, were asked about the reasons of using ICT sources to get information. All farmers reported that due to lower cost and low consumption of time, they found ICT as the reliable source to get information. About $69 \%$ farmers reported that by using ICT they could find wider market areas for their agricultural products. About $62 \%$ farmers said that information from ICT sources helped to find large number of buyers which created more option for them to choose and increasing bargaining power with the buyer of their product.

Differences in quality of decision on various marketing practices

The quality perceptions of the farmers on various aspects of agricultural marketing were recorded on a five point Likert scale. The results of mean scores of information quality and analysis of variance between users and non-users of ICT based information sources on
9 dimensions of marketing decision-making are given in Table 2.

The results on mean value of ICT user farmers for various marketing practices were less than 2 in most of the cases, which clearly indicated that farmers received quality information for marketing decision-making. The results also indicated that the mean scores on all the parameters of marketing practices were lower in case of ICT users as compared to non-users. In order to analyze the difference in quality of information received by them, analysis of variance (ANOVA) was carried out. Results of the analysis indicated that the value of Fstatistics were significant at $1 \%$ level of significance for various decisions regarding different marketing practices.

Here, it can be seen farmers both ICT user and non-user were not collecting information on all the marketing practices. They were collecting only that information which were more needed to them. However, the usage of information on selling, sales price and input price practices were high among both ICT users and nonusers. So, it is evident from the findings that the users of ICT based information were getting better quality information and hence, making significantly better decisions on all aspects of agricultural marketing. Jabir, (2011) found the same result where the livestock farmers who were ICT users were getting better quality information and hence, made better decisions on all aspects of livestock farming. The results also indicated that the mean scores on all the parameters of livestock rearing and marketing were lower in case of ICT users as compared to non-users. The information on market price, marketing and selling using various ICT sources helped them to make better quality decisions than the non-user of ICT. So, it implies that there is a huge potential to increase the quality of decision regarding agricultural marketing by modern technologies.

Table 2. Differences in Quality of Decision between ICT user and Non-User farmer

\begin{tabular}{|c|c|c|c|c|c|c|c|}
\hline \multirow[t]{2}{*}{ Marketing Practices } & \multicolumn{3}{|c|}{ ICT User } & \multicolumn{3}{|c|}{ Non-ICT user } & \multirow[b]{2}{*}{ F-Value } \\
\hline & $\mathrm{N}$ & Mean & $\begin{array}{c}\text { Standard } \\
\text { Deviation }\end{array}$ & $\mathrm{N}$ & Mean & $\begin{array}{c}\text { Standard } \\
\text { Deviation }\end{array}$ & \\
\hline Market Planning & 35 & 1.74 & .701 & 28 & 4.11 & .832 & $53.81 *$ \\
\hline Selling & 45 & 1.82 & .535 & 35 & 3.80 & .933 & $54.44 *$ \\
\hline Transportation & 40 & 1.82 & .446 & 29 & 3.34 & .614 & $107.671 *$ \\
\hline Storage & 38 & 1.97 & .592 & 26 & 3.77 & .815 & $17.890^{*}$ \\
\hline Sales price & 45 & 1.22 & .420 & 35 & 2.73 & .822 & $66.74 *$ \\
\hline Market Demand & 44 & 1.41 & .542 & 29 & 3.72 & .528 & $90.90 *$ \\
\hline Buyers Availability & 42 & 1.57 & .630 & 28 & 3.68 & .670 & $46.09 *$ \\
\hline Market Availability & 43 & 1.70 & .708 & 27 & 3.59 & .694 & $44.95 *$ \\
\hline Input Price & 45 & 1.51 & .549 & 35 & 2.86 & .810 & $32.793 *$ \\
\hline
\end{tabular}

*Significant at the 0.01 level

Source: Field Survey 2017

Note: Responses in five points Likert scale indicated as very $\operatorname{good}=1$, good $=2$, neutral $=3$, poor $=4$ and very poor $=5$ 


\section{Factors affecting ICT use by the farmers}

Multivariate linear regression model was employed to analyze the factors that affect the use of ICT. Before estimating the parameters, multicollinearity test was performed using VIF (Variance Inflation Factor). A VIF for continuous variables and coefficient values for discrete variables were computed to check the existence of multicollinearity problem. The results revealed that VIF values of all variables were less than five that means there was no significant problems of multicollinearity and high degree of association among discrete variables were detected. The econometric results in Table 3 shows that there were 7 hypothesized determinants of factors affecting ICT use in agricultural marketing. Among them, two variables were found significant effect on ICT use in agricultural marketing. These are education level of farmers and their cultivated land. The coefficients of multivariate determinations $\left(\mathrm{R}^{2}\right)$ was estimated 0.58 and adjusted $\mathrm{R}^{2}$ was 0.54 . This means that $58 \%$ variation in the dependent variable is explained by the explanatory variables included in the model. Furthermore, the adjusted $\mathrm{R}^{2}$ of $54 \%$ which is significant has further consolidated the goodness of model, hence, its econometric significance and reliability.

Table 3. Factors affecting ICT use in agricultural marketing by farmers

\begin{tabular}{|l|c|c|c|c|}
\hline Independent variable & Coefficients & Standard error & p-value & VIF \\
\hline Constant & -0.053 & 0.272 & 0.84 & \\
\hline Age of the respondents & 0.008 & 0.006 & 0.18 & 2.12 \\
\hline Cultivated land of the respondents & 0.045 & 0.019 & 0.01 & 2.45 \\
\hline Experience in farming & 0.005 & 0.007 & 0.49 & 3.06 \\
\hline Household size & -0.019 & 0.046 & 0.67 & 2.22 \\
\hline Educational level of the respondent & 0.112 & 0.045 & 0.01 & 2.31 \\
\hline Basic ICT skill & -0.131 & 0.124 & 0.29 & 2.17 \\
\hline Skill upgrading training & -0.082 & 0.121 & 0.50 & 1.87 \\
\hline F-statistics & \multicolumn{3}{|c}{} \\
\hline R square & \multicolumn{3}{|c|}{0.58} \\
\hline Adjusted R square & \multicolumn{3}{|c}{0.54} \\
\hline
\end{tabular}

The result revealed that cultivated land of farmers had a positive effect on ICT use in marketing of their agricultural product and significant at $1 \%$ probability level. The model output predicts that the addition of oneacre land caused the increase in the use of ICT in agricultural marketing by .04 units. The result suggests that the amount of cultivated land of the farmer in the study areas was more responsive to the use of ICT in agricultural marketing by farmers.

The level of education had a positive effect on the use of ICT by farmers for marketing their agricultural product and was statistically significant at $1 \%$ probability level. The result suggests that if the farmers were educated, the use of ICT in agricultural marketing would be increased through its effect. The model also confirmed that the increase in one grade in education level leads to a rise in use of ICT by 0.11 units by the farmers. Vosough, (2015) found that education and knowledge level of ICT, the amount of land under cultivation were factors that significantly influence the using of ICT by farmers. Formal education enhances the information acquisition and adjustment abilities of the farmer, thereby improving the quality of decision making (Fakoya et. al., 2007). In general, more educated farmers with more land under cultivation have a greater tendency of using ICTs. Not only the people's educational level, but also their access to communication media provided a fruitful context and had led them to adopt to put into practice their knowledge of the new technology. An educated farmer is always in a favorable position in using information from different ICT sources as he has basic knowledge about it. The sampled farmers who are using ICT in the study area were educated enough (as stated in the educational status of the respondents). Besides this, the respondents mentioned that they were either getting help from their family members who are friendly with the technologies or the agriculturist of the Zill Bangla Sugar Mills helped them to get market related information through ICT.

\section{Conclusion}

The use of ICT devices by farmers was affected by different socioeconomic factors such as cultivated land area and education level of the farmers in the study area which had shown significantly positive correlation with the use of ICT by farmers. The study also provides practical insights into effectiveness of various sources of information and suggests areas of improvement in the information delivery processes. For example, the benefits of most of the information delivery on marketing practices were towards ICT users while the non-ICT users were not getting all information on marketing their produces. Therefore, it is clear that the provision of ICT should be in such way that all farmers can get information according to their demand are to be benefitted equivalently. Sometimes farmers are willing to accept ICTs but they don't have knowledge of using them. Therefore, the government and private organizations should provide appropriate knowledge 
generating activities to the farmers to accept the ICTs in agricultural marketing decision making.

\section{References}

Aker, J.C. (2010). Does Digital Divide or Provide? The Impact of Cell Phones on Grain Markets in Niger, University of California, Berkeley.

Dao, M.Q. (2004) "Rural poverty in developing countries: an empirical analysis", Journal of Economic Studies, 31(6): 500-508. https://doi.org/10.1108/01443580410569244

Fakoya, O.M., and Agbonlahor, D. A. (2007). Attitude of women farmers towards sustainable land management practices in South-Western Nigeria, World Journal of Agricultural Sciences, 3(4); 536-542.

Hasan, R., Islam, S., Rahman, M.S. and Jewel, K.N.A. (2009). Farmers Access to Information for Agricultural Development in Bangladesh, Bangladesh Res. Pub. J., 2(1): 319-331.

Jabir, A., (2011). Use of quality information for decision-making among livestock farmers: Role of Information and Communication Technology, Livestock Research for Rural Development, 23 (3)

James, Ga., Witten, D., Hastie, T. and Tibshirani, R. (2017). An Introduction to Statistical Learning $\left(8^{\text {th }}\right.$ ed.), Springer Science Business Media, New York.

Kashem, M.A., Faroque, M.A.A., Ahmed, G.M. F., and Bilkis, S.E. (2010). The Complementary Roles of Information and Communication Technology in Bangladesh Agriculture, J. Sci. Foundation, 8 (1\&2): 161-169. https://doi.org/10.3329/jsf.v8i1-2.14639
Likert, R., (1932). A Technique for the Measurement of Attitudes, Archives of Psychology, 140; 1-55.

Mawazo, M. M. (2015). Linking Rural Farmers to Markets Using ICTs, CTA working paper 15/12, The Nelson Mandela African Institution of Science and Technology, South Africa.

Rahman, T. (2016). The Potential of ICT for Agriculture in Bangladesh, The Independent, Dhaka, Bangladesh.

Rao, N. (2007). A Framework for Implementing Information and Communication Technologies in Agricultural Development in India, Journal of Technological Forecasting and Social Change, 74(4): 491-518. https://doi.org/10.1016/..techfore.2006.02.002

Todaro, M.P. (2000). Economic Development, Addison Wesley Longman Inc., $1^{\text {st }}$ Edition, pp. 363-375.

Vakilzavareh, F., Lashgarara, F, and Mirdamadi, M.S. (2014). Requirements and Challenges of Using ICT in the Marketing of Agricultural Products from the Viewpoint of Agricultural Experts, International Journal of Review in Live Sciences, 4(7): 1-5.

Venkatesh, V., Brown, A.S. and Bala, H., (2013). Bridging the Qualitative-Quantitative Divide: Guidelines for Conducting Mixed Methods Reseach in Information Systems. Management Information Systems Quarterly, 37 (1). p.54. https://doi.org/10.25300/MISQ/2013/37.1.02

Vosough, A., and Eghtedari, N. (2015). Factors Affecting ICT Adoption in Rural Area: A Case Study, Research Journal of Fisheries and Hydrobiology, 10(10): 611-616. 